\title{
Eco-friendly Concrete Using Local Materials From Sudan
}

\author{
Salma Yahia Mohamed Mahmoud \\ salmaymm@gmail.com \\ College of Engineering, University of Science and Technology, Omdurman, Sudan \\ El Tahir Abualgasim Mohammed Alshiekh \\ schoolcivil@yahoo.com \\ College of Engineering, Sudan University of Science and Technology, Khartoum, Sudan
}

\begin{abstract}
This study is aimed at investigating the potentiality for utilizing some locally available eco-friendly materials to replace some concrete constituents as a possible opportunity to introduce sustainable construction in Sudan. Six suggested scenarios were explored to visualize the possible outcomes : (1) 100\% recycled aggregates (RA) and natural pozzolana in replacement of coarse aggregates (2) steel slag replacing fine aggregate or cement (3) treated sawdust replacing fine aggregates (4) sawdust ash in partial replacement of cement (5) meta-kaolin (MK) in partial substitution for ordinary Portland cement (OPC) (6) quarry dust (QD) in partial replacement of sand or cement. Laboratory experiments were conducted and concrete workability and compressive strength were determined. The results confirmed the suitability of RA for full replacement of natural coarse aggregates. Steel slag was more appropriate in replacing sand than cement when added in small percentages not exceeding 15\%. Sawdust needed treatment to eliminate the unfavorable properties before using it as a substitute for sand but when the ash was used to replace cement, it was not possible to achieve the required strength at early ages and better results were achieved in 28 days. With a chemical composition comparable to cement, MK showed impressive results when used in partial replacement of OPC. The addition of QD in replacement of $15 \%$ of sand offered a reasonable workability but the compressive strength was only approaching the targeted value. According to these results, it could be inferred that the tested options offer reasonable evidence to confirm their potentiality for producing green concrete in Sudan.
\end{abstract}

Keywords: Green concrete; Meta-kaolin; Sudan; Sustainability

\section{INTRODUCTION}

Concrete is a heavy, rough building material made from a mixture of cement, fine and coarse aggregates, water and maybe some additives. For the negative impacts resulting from its production, concrete has been classified as environmentally unfriendly. Its production consumes natural resources such as river sand, clays and rocks which are normally not returned back and involves the emission of huge amounts of $\mathrm{CO}_{2}$ during the production of cement-as one of its major constituents. Accordingly, sustainable trails in the building industry called for preserving these natural resources through the production of eco-friendly concrete. This is concrete where waste materials are used as at least one of its components or its production does not lead to environmental destruction through the reduction, reuse or recycling techniques. 


\section{SUSTAINABILE ALTERNATIVE BUILDING MATERIALS}

The call for cement and concrete production sustainability was stressed in several previous studies. Green concrete is thought to be one of the solutions leading to sustainable construction because it "... uses waste material as at least one of its components, or its production process does not lead to environment destructions" (Akbarnezhad et al., 2013; De Brito \& Saikia, 2013). They evaluated the physical and mechanical properties of different material options when used in substitution for some of the main components of concrete. Durga and Andira (2016) tested the use of construction debris and demolition waste, for partial or entire replacement of virgin aggregate when making new concrete and argued that it "... could save about $60 \%$ of limestone resources and reduce $\mathrm{CO}_{2}$ emissions by about $15 \%-20 \%$ ". It has been reported though that there are some limitations recorded on its use pertaining to its long-term durability. It was found that variation in the RA properties, different environmental conditions in addition to the crushing process, contamination and impurities, affect the new concrete properties (El Shiekh et al., 2012; Mahmoud \& El Shiekh, 2018; Juenger et al., 2012; McNeil \& Kang, 2013; Mehta, 2010; Pachipala, 2017).

The use of alternative materials to replace aggregates was another option to avoid depleting the natural aggregates. Silica sand, a by-product of the glass industry, is an alternative incorporated to partially replace natural sand in concrete mixtures (Pimraksa et al., 2018; Silva et al., 2015). The results showed up to $32 \%$ increase in compressive strength and $13 \%$ improvement on tensile strength upon replacement of natural sand by $60 \%$ and $40 \%$ respectively (Ulloa et al., 2013).

The behavior of concrete with supplementary cementitious materials (SCM) has been investigated in many studies. "Natural supplementary materials such as volcanic rock and limestone are used for their economic benefit and early-strength and durability improvements" (Vishnumanohar, 2014). Among the commonly used SCM are coal fly ash, silica fumes, metakaolin and blast furnace slag (Xiao et al., 2014). Calcined clays, municipal solid waste incinerator residues and limestone fillers are few examples cited in the literature where their use as alternative supplementary materials was outlined.

\section{TRIALS TO PRODUCE ECO-FRIENDLY CONCRETE IN SUDAN}

Initially, the chemical and physical properties of the different materials used in these trials were determined, different mix designs considering several options were developed then the concrete was prepared and casted in cubes. The fresh concrete mixtures were tested for workability and the hardened concrete was tested for compressive strength after 7, 14 and 28 and in some instances for 90 in all trials.

\section{$3.1100 \%$ recycled aggregates (RA) and natural pozzolana in replacement of coarse aggregates}

This study built on a preliminary study conducted by the authors on the reuse of building demolition wastes and their potential usefulness in producing new concrete. More investigation scenarios were included. The physical properties of fresh and hardened RCA included concrete were investigated with and without natural pozzolana being added to the mixtures. OPC conforming to (BS-8112-1996) was used with $32.5 \%$ normal consistency, 2 hours and 25 minutes initial setting time, 3 hours and 30 minutes 
final setting time, $2 \%$ fineness and $2 \mathrm{~mm}$ stability size. Specific gravity and absorption were determined as shown in table 1.

Table 1: Aggregates Characteristics

\begin{tabular}{|c|c|c|}
\hline Characteristics & $\begin{array}{c}\text { Natural Coarse Aggregates } \\
\text { (NCA) }\end{array}$ & $\begin{array}{c}\text { Recycled Coarse Aggregates } \\
\text { (RCA) }\end{array}$ \\
\hline Specific Gravity & 2.76 & 2.66 \\
\hline Absorption & 0.44 & 0.98 \\
\hline
\end{tabular}

The recycling process involved crushing, separation of metals by a magnet, manual removal of other impurities (plastic, wood, etc.), and classification of aggregates to different grades based on particle size as illustrated in Figures 1a, 1b, 1c respectively.

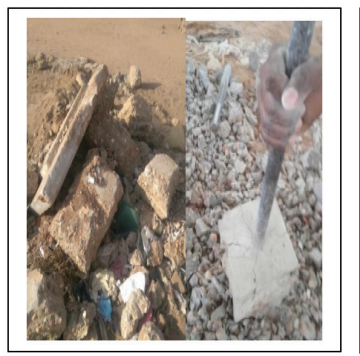

Figure 1a: Aggregates crashing

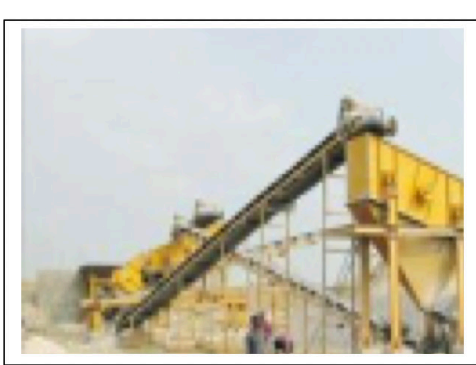

Figure 1b: Metals separation

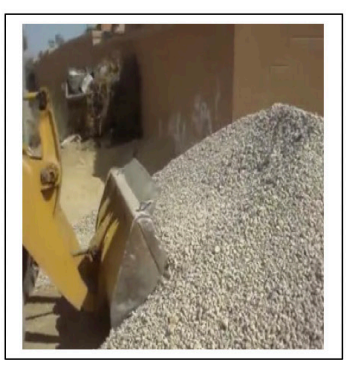

Figure 1c.: Aggregates classification

Proportions for 8 different mix trials were considered and the materials proportions are presented in table 2 . The targeted compressive strength value was $(25 \mathrm{MPa})$.

Table 2: Mix Trials materials proportions

\begin{tabular}{|c|c|c|c|c|c|c|}
\hline Trial & $\begin{array}{c}\text { Cement } \\
(\mathrm{Kg})\end{array}$ & $\begin{array}{c}\text { Water } \\
(\mathrm{Kg})\end{array}$ & Fine Aggregate $(\mathrm{Kg})$ & NCA $(\mathrm{Kg})$ & $\begin{array}{c}\text { RCA } \\
(\mathrm{Kg})\end{array}$ & $\begin{array}{c}\text { Pozzolana } \\
(\mathrm{Kg})\end{array}$ \\
\hline 1 & 325 & 195 & 641 & 1189 & - & - \\
\hline 2 & 325 & 195 & 641 & 891.8 & 297.3 & - \\
\hline 3 & 325 & 195 & 641 & 594.5 & 594.5 & - \\
\hline 4 & 325 & 195 & 641 & 297.3 & 891.8 & - \\
\hline 5 & 325 & 195 & 641 & - & 1189 & - \\
\hline 6 & 292.5 & 195 & 641 & - & 1189 & 32.5 \\
\hline 7 & 260 & 195 & 641 & - & 1189 & 65 \\
\hline 8 & 227.5 & 195 & 641 & - & - & 97.5 \\
\hline
\end{tabular}

Slump test values ranged between $60-180 \mathrm{~mm}$. However, workability was noticed to decrease in the range of $4.2-14.3 \%$ with increasing replacement ratios of RCA up to a maximum of $20.2 \%$ with $100 \%$ RCA in comparison to NCA. Contrary wise, an increase in the range of 3.2-7.4\% was reported with the inclusion of pozzolana with $100 \%$ RCA concrete. In its fresh state, the optimum ratio was achieved with the full replacement with RCA and $20 \%$ pozzolana. Compressive strength results depicted in figure 2 showed a strength decrease as the RCA replacement percentage increases. The target strength was achieved with $10 \%$ pozzolana and $100 \%$ RCA. 


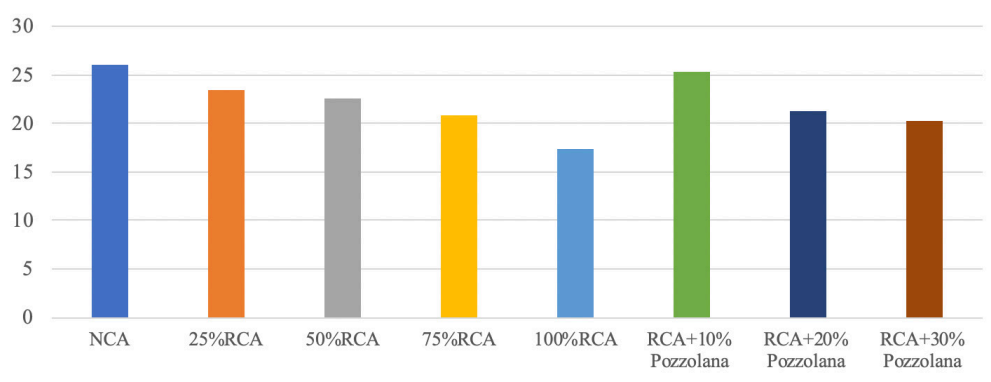

Figure 2: 28-Days compressive strength results for the different mix trials

The results for the durability test presented in Figure 3, revealed a drop in the wave speed value $(\mathrm{Km} / \mathrm{sec})$ when the NCA were completely replaced by RCA while an increase was witnessed with the different percentages of Pozzolana added to mix.

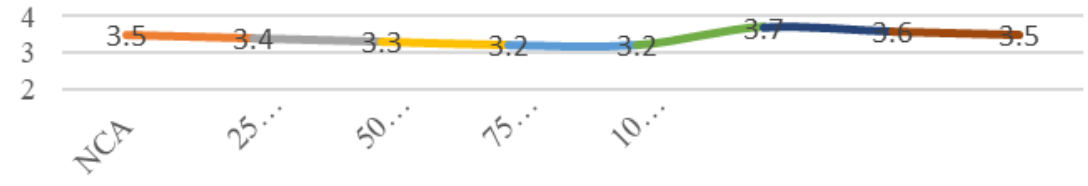

Figure 3: Durability Test Results (Wave speed Km/sec)

\subsection{Steel slag replacing fine aggregate or cement}

Blast furnace slag (BFS), a by-product from the production of steel at Giad Factory south of the city of Khartoum - Sudan was used. Both chemical analysis and XRD test were conducted on a BFS sample and the results showed similar oxides in comparison to OPC but with different proportions $\left(\mathrm{SiO}_{2}, 33 \% ; \mathrm{Al}_{2} \mathrm{O}_{3}, 7 \%, \mathrm{Fe}_{2} \mathrm{O}_{2}, 11 \%\right)$. It was incorporated in partial substitution for sand then cement in concrete mixtures.

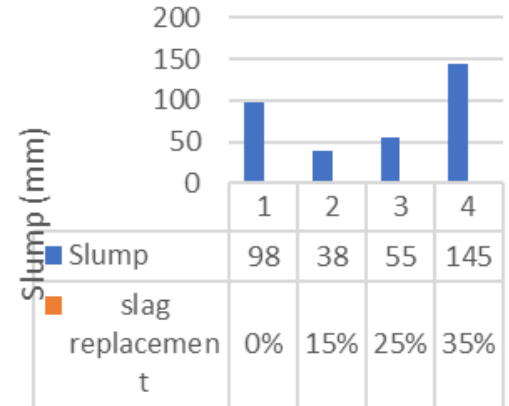

Figure 4a: Workability Results for mixtures containing Steel Slag in Replacement for Sand

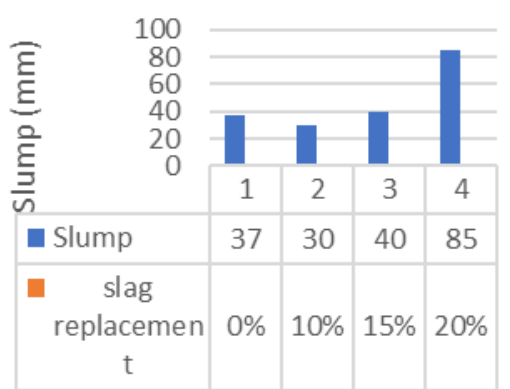

Figure 4b: Workability Results for mixtures containing Steel Slag in Replacement for Cement 


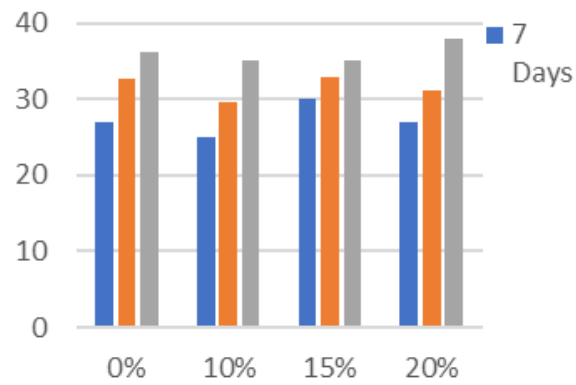

Figure 5a: Compressive Strength Results for Concrete with the Inclusion of Steel Slag in Replacement for Sand

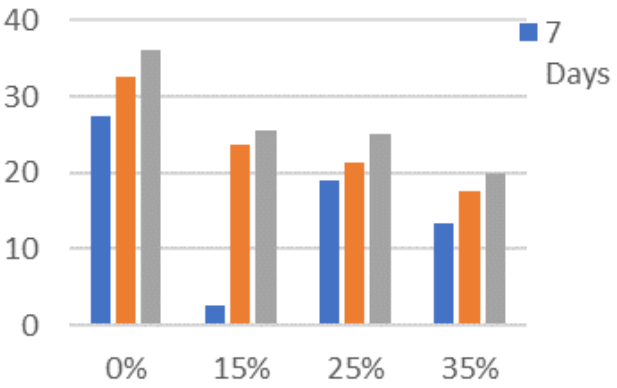

Figure 5b: Compressive Strength Results for Concrete with the Inclusion of Steel Slag in Replacement for Cement

A standard mix and 3 others where the slag replaced $(10 \%, 15 \%$, and $20 \%)$ of the sand weight and $(15 \%, 25 \%$, and $35 \%)$ of the cement weight. The slump and compressive strength results are shown in figures $4 \mathrm{a}, 4 \mathrm{~b}$, and $5 \mathrm{a}, 5 \mathrm{~b}$. The results for slag replacement for sand confirmed that both the workability and the compressive strength have increased. Alternatively, in the case of replacing the slag with varying percentages of the cement weight, the results showed an increase in workability parallel with the increase in the slag amount while the compressive strength has dropped.

\subsection{Treated sawdust replacing fine aggregates}

Samples of the abundantly available sawdust (SD) from the local furniture market on Khartoum State, Sudan were collected, treated then used in concrete mixtures. Seven cases, shown in table 3 , were analyzed. Compressive strength at the different curing ages was as illustrated in table 3 .

Table 3: Compressive strength results for treated Sawdust included in replacement of fine Aggregates Concrete mixtures

\begin{tabular}{|l|c|c|c|}
\hline \multirow{2}{*}{ Scenario } & \multicolumn{3}{|c|}{ Streangth (MPa) } \\
\cline { 2 - 4 } & 7 Days & 14 Days & 28 Days \\
\hline Untreated Sawdust & 34.5 & 37.03 & 38.96 \\
\hline $\begin{array}{l}\text { Unsoaked Sawdust with 10\% } \\
\text { repalcement }\end{array}$ & 8.77 & 9.31 & 6.8 \\
\hline $\begin{array}{l}\text { Unsoaked Sawdust with 20\% } \\
\text { repalcement }\end{array}$ & 2.08 & 3.9 & 18.07 \\
\hline $\begin{array}{l}\text { soaked Sawdust with 10\% } \\
\text { repalcement }\end{array}$ & 16 & 15.9 & 17.8 \\
\hline $\begin{array}{l}\text { soaked Sawdust with 20\% } \\
\text { repalcement }\end{array}$ & 11.5 & 13.8 & 18.1 \\
\hline $\begin{array}{l}\text { Sawdust treated with calcium } \\
\text { hydroxide + 10\% MC }\end{array}$ & 15.13 & 11.3 & 12.3 \\
\hline $\begin{array}{l}\text { Sawdust treated with calcium } \\
\text { hydroxide + 20\% MC }\end{array}$ & 3.24 & 5.5 & \\
\hline
\end{tabular}


The unfavorable properties of SD made if hardly possible to approach the targeted strength. With unsoaked SD, 10\% replacement offered better results and when the dust was soaked nearly equal results were obtained for 10 and $20 \%$ replacement which are also equal to the strength value $10 \%$ replacement when the SD was treated with the calcium hydroxide and coated with varnish.

\subsection{Sawdust ash in partial replacement of cement}

The ash was prepared as depicted in figures $6 \mathrm{a}, 6 \mathrm{~b}, 6 \mathrm{c}$ and $6 \mathrm{~d}$ and the mix trials were prepared with the proportions shown in table 4

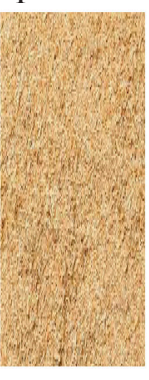

Figure 6a: Raw Sawdust

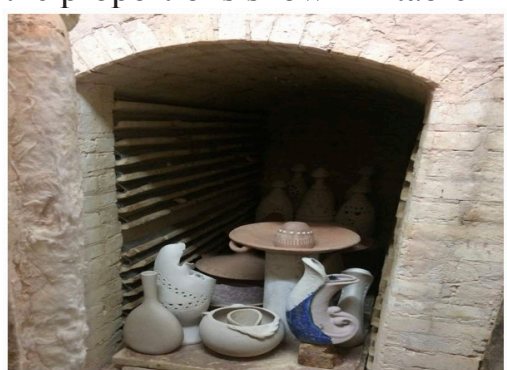

Figure 6b: Sawdust burning
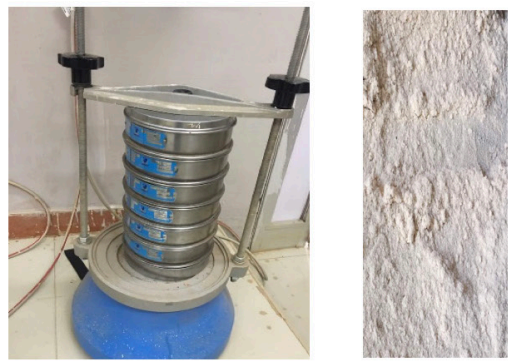

Figure 6c: Sawdust ash sieving
Figure 6d: Hardened sawdust concrete mix

Table 4: Compressive strength results for Sawdust ash included in replacement of cement in Concrete mixtures

\begin{tabular}{|c|c|c|c|}
\hline \multirow{2}{*}{$\begin{array}{c}\text { Mix Trial (\% } \\
\text { replaced) }\end{array}$} & \multicolumn{2}{|c|}{ Compressive strength (MPa) } & Slump (mm) \\
\cline { 2 - 4 } & 7 days & 28 days & \\
\hline $0 \%$ & 24.1 & 37.67 & 37 \\
\hline $10 \%$ & 18.14 & 22.04 & 35 \\
\hline $20 \%$ & 15.87 & 24.9 & 34 \\
\hline
\end{tabular}

Better results are achieved when the ash was used in replacement for cement. Slump values are within the designed for limit $(30-60 \mathrm{~mm})$ and the compressive strength is just as the targeted value with $20 \%$ replacement ratio.

\subsection{Meta-kaolin (MK) in partial substitution for ordinary Portland cement (OPC)}

A two stages process was followed. The first stage was concerned with the kaolinite clay $(\mathrm{KC})$ collected from different locations in Sudan. The chemical composition was determined using X-Ray florescence where the major oxides were identified then compared to the major constituents of OPC. KC was transformed to Meta-Kaolin (MK) through a calcination process then tested according to the ASTM-C618 to determine its pozzolanicity. The evaluation of the pozzolanic activity of the MK was conducted via chemical and mechanical tests. The former comprised measurement of the amount of the three major oxides $\left(\mathrm{SO}_{2}+\mathrm{Al}_{2} \mathrm{O}_{3}+\mathrm{Fe}_{2} \mathrm{O}_{3}\right)$, Loss on ignition percent and the later was concerned with assessing the strength properties of $\mathrm{MK}$ included concrete. The results shown in table 5 , confirmed the pozzolanicity of the MK. 
Table 5: The evaluation of the pozzolanicity activity of the Meta-Kaolin from Sudan

\begin{tabular}{|c|c|c|c|c|c|}
\hline \multirow{2}{*}{ Elements } & \multicolumn{4}{|c|}{ Meta-kaolin from different locations in } & Pozzolanicity \\
\cline { 2 - 5 } & Site 1 & Site 2 & Site 3 & Site 4 & $\begin{array}{c}\text { Limits according to } \\
\text { ASTM C618 (\%) }\end{array}$ \\
\hline $\mathrm{SiO}_{2}+\mathrm{Fe}_{2} \mathrm{O}_{3}+\mathrm{Al}_{2} \mathrm{O}_{3}$ & 93.05 & 88.42 & 97.30 & 97.60 & $\geq 70 \%$ \\
\hline $\mathrm{LOI}$ & 4.08 & 5.65 & 0.68 & 1.3 & $\leq 6 \%$ \\
\hline
\end{tabular}

MK was then added to concrete mixtures in $(0,5,10,15,20,30) \%$ replacement for cement. Workability of the fresh concrete samples was tested through the slump test where all results were conforming to the required limit $(60-180 \mathrm{~mm})$ then a set of $56(150 \times 150 \times 150) \mathrm{mm}$ cubes were casted and cured for 7,14,28,90 days. The results depicted in figure 7 show an increase in the strength with the MK inclusion with an optimum limit of $20 \%$ yielding $35.8 \mathrm{MPa}$ in 28 days. It was also evident that very promising results could be achieved at long ages as shown in 20 and 30\% MK which yielded 40.1 and $42.3 \mathrm{MPa}$ respectively exceeding by that the targeted strength and indication the pozzolanic reactivity of the MK at longer ages.

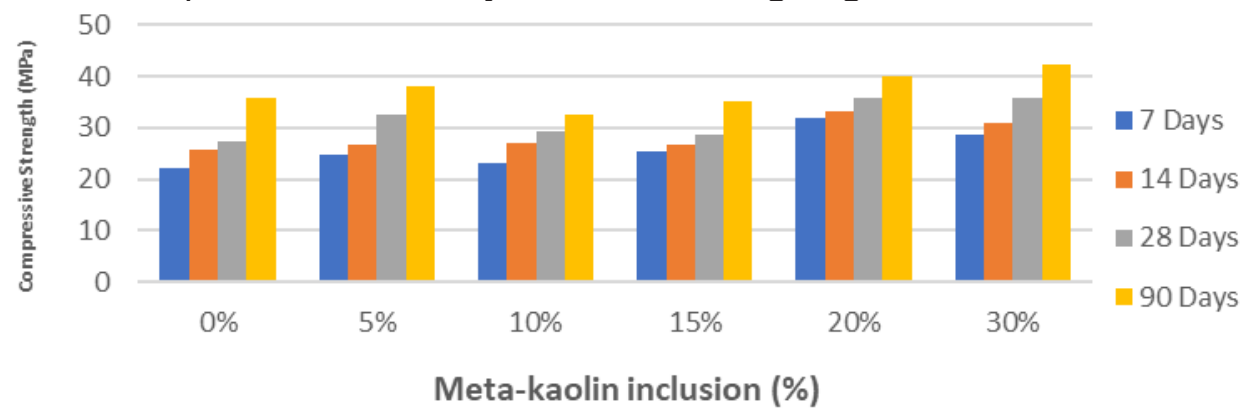

Figure 7: Compressive strength of meta-kaolin included concrete mixtures

\subsection{Quarry dust (QD) in partial replacement of sand}

Quarry dust is a sediment or residue from the process of extracting and treating rocks. For this study, the dust was obtained from two locations; (Toureah) Mountain, south of Omdurman, and Algabaleen. When collected its physical appearance is as depicted in figures $8 \mathrm{a}$ and $8 \mathrm{~b}$.

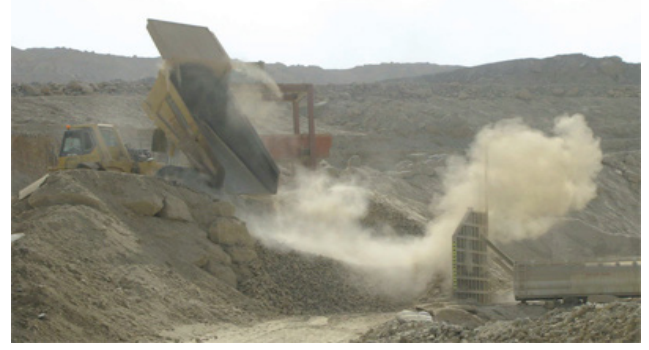

Figure 8a: Quarry Dust Collection

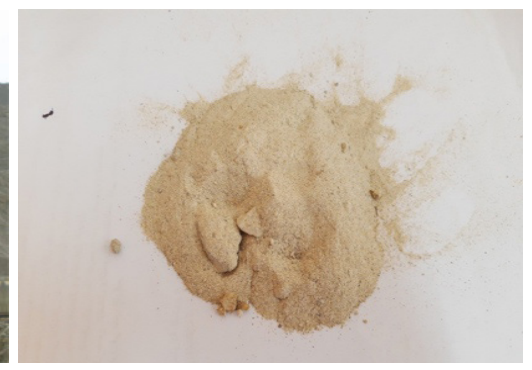

Figure 8b: Collected Dust

In replacement for sand, concrete mixtures containing $(15 \%, 25 \%, 35 \%)$ of the QD and in replacing cement $(15 \%, 25 \%, 50 \%)$ were designed and prepared then cured in water. Workability of fresh concrete was measured for all mixtures and the compressive 
strength of hardened concrete was defined for 7 and 28 days. The results showed that the target strength was nearly achieved in the two cases. The replacement of sand by $15 \%$ QD yielded the best results among the mixing ratios while further increase in the dust reduced the compressive strength. In replacing cement, the optimum results were achieved with $25 \%$ replacement for cement, refer to figures $9 a$ and $9 b$ ).

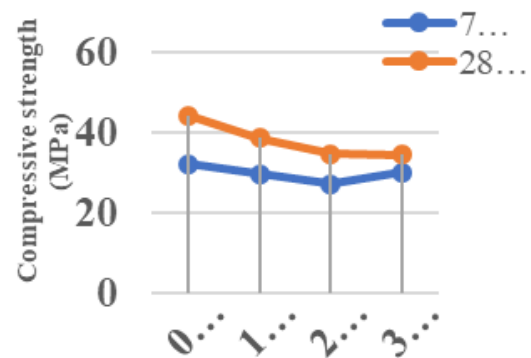

Figure 9a: Quarry Dust inclusion (\%) from Omdurman-Sudan

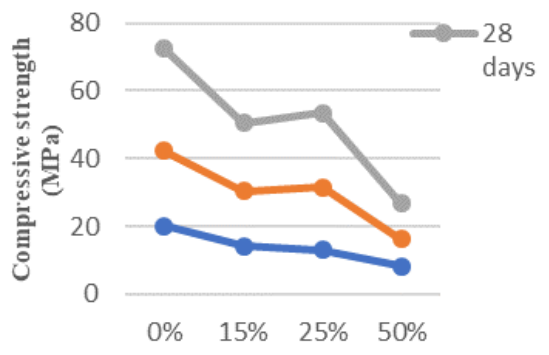

Figure 9b: Quarry Dust inclusion (\%) from Algabaleen-Sudan

\section{CONCLUSION}

The results confirmed the suitability of RA for full replacement of natural coarse aggregates. Steel slag was more appropriate in replacing sand than cement when added in small percentages not exceeding $15 \%$. Sawdust needed treatment to eliminate the unfavorable properties before using it as a substitute for sand but when the ash was used to replace cement, it was not possible to achieve the required strength at early ages and better results were achieved in 28 days. With a chemical composition comparable to cement, MK showed impressive results when used in partial replacement of OPC. The addition of QD in replacement of $15 \%$ of sand offered a reasonable workability but the compressive strength was only approaching the targeted value. According to these results, it could be inferred that the tested options offer reasonable evidence to confirm their potentiality for producing green concrete in Sudan.

\section{REFERENCES}

Akbarnezhad, A., Ong, K. C. G., Tam, C. T. \& Zhang, M. H. (2013). Effects of the parent concrete properties and crushing procedure on the properties of coarse recycled concrete aggregates. Journal of Materials in Civil Engineering, Vol. 25, No. 12, pp. 1795-1802.

De Brito, J. \& Saikia, N., (2013). Recycled aggregate in concrete: Use of industrial, construction and demolition waste. London, the UK: Springer.

Durga, B. \& Andira, M. (2016). Experimental study on various effects of partial replacement of fine aggregate with silica in cement concrete and cement mortar. International Journal of Engineering Trends and Technology (IJETT), Vol. 33, no. 5.

El Shiekh, A. A., Mahmoud, S. Y. \& Attaalmanan, M. (2012). Study of the effect of steel slag on some of the properties of concrete. Sudan Engineering Society Journal, Vol. 57, No.1, pp1-8.

Juenger, M., John, L. P., Elsen, J., Winnie, M. \& Doug, H. R. (2012). Supplementary cementitious materials for concrete: Characterization needs, Materials research society symposium proceedings. Vol. 1488. 
Mahmoud, S. \& Elshiekh, E. (2018). The potential usefulness of recycled aggregates and pozzolana in producing green concrete in Sudan. International Journal of Structural and Civil Engineering Research. Vol. 7, No.2.

McNeil, K. \& Kang, T. H. K. (2013). Recycled concrete aggregates: A review. International Journal of Concrete Structures and Materials, Vol. 7, No.1, pp. 61-69.

Mehta, P. K. (2010). Sustainable cements and concrete for the climate change era - a review, Proceedings of the 2nd International Conference on Sustainable Construction Materials and Technologies. Ancona, Italy, pp. 28-30.

Pachipala, S. (2017). A study on mechanical properties of concrete using silica sand as partial replacement of cement. International Journal of Civil Engineering (SSRC-IJCE), Vol. 4, No. 5, pp. 34-39.

Pimraksa, K. P., Chindaprasirt, J. S. \& Ling, T. C. (2018) Alternative cementitious materials and their composites. Advances in Material Science and Engineering, Vol. 2018, article 50746.

Silva, R. V., de Brito, J. \& Dhir, R. K. (2015). Prediction of the shrinkage behavior of recycled aggregate concrete: A review. Construction and Building Materials, Vol. 77, pp. 327-339.

Ulloa, V. A., García-Taengua, E., Pelufo, M. J., Domingo, A. \& Serna, P. (2013). New views on effect of recycled aggregates on concrete compressive strength. ACI Materials Journal, Vol. 110, No. 6, pp. 1-10.

Vishnumanohar, A. (2014). Performance of normal concrete with eco sand (finely graded silica) as fine aggregate. International Journal of Engineering Science Invention, Vol 3, No. 5, pp. 27-35.

Xiao, J., Li, L., Tam, V. W. \& Li, H. (2014). The state of the art regarding the long-term properties of recycled aggregate concrete. Structural Concrete, Vol. 15, No. 1, pp. 3-12. 